\title{
Pengaruh Pengawasan dan Fasilitas terhadap Kinerja Penyuluh Dinas Pertanian Kabupaten Labuhanbatu Utara yang Dimoderasi dengan Motivasi
}

\author{
Darma Aditya', Jufrizen ${ }^{2}$, Hazmanan Khair ${ }^{3}$ \\ 1,2,3 Universitas Muhammadiyah Sumatera Utara, Indonesia
}

Corresponding Author: aditya_darma99@yahoo.com

ABSTRACT
This study aims to determine the effect of supervision and facilities on
moderating the effect of supervision and facilities on the performance of
the extension worker at the North Labuhanbatu Regency Agricultural
Office. This study uses a causal associative method with a quantitative
descriptive approach to explain the causal relationship and influence
between variables through hypothesis testing. The results showed that
the effect of supervision and facilities on the performance of the
agricultural extension workers in North Labuhanbatu Regency based on
the indicators were as follows: First, there was a positive and significant
influence between supervision on the performance of the extension
workers, which means that if the supervision improves, the performance
of the instructor will automatically increase as well. Second, there is a
positive and significant effect between the facilities on the performance of
the instructor, which means that if the facility increases, the performance
of the instructor will improve. Third, motivation does not moderate the
effect of supervision on the performance of the instructor. Fourth,
motivation does not moderate the influence of facilities on the
performance of the instructor. Directly motivation has a positive and
significant effect on the performance of the instructor. It is hoped that the
Department of Agriculture of North Labuhanbatu Regency will improve
existing supervision and increase the provision of facilities for extension
workers to improve their performance.
Supervision, Facilities, Motivation, Extension Performance
Keywords

\section{PENDAHULUAN}

Kinerja pegawai merupakan sesuatu yang perlu diperhatikan oleh organisasi maupun instansi pemerintah. Kinerja pegawai akan mempengaruhi kualitas perusahaan dalam menghadapi persaingan seiring dengan perkembangan globalisasi. "Kinerja adalah hasil kerja secara kualitas dan kuantitas yang dicapai oleh seorang pegawai dalam melaksanakan tugasn sesuai dengan tanggung jawab yang diberikan kepadanya" (Mangkunegara, 2018).

Tercapainya tujuan merupakan keinginan setiap organisasi. Indikatornya dapat dilihat dari terlaksananya perencanaan baik jangka pendek maupun jangka panjang. Dibutuhkan peran serta secara aktif dari setiap unsur dalam 
organisasi agar perencanaan dapat terlaksana dengan baik. "Bila setiap unsur dalam organisasi berusaha berkontribusi dengan baik, maka prestasi organisasi akan diperoleh. Diperlukan penilaian kinerja dari setiap komponen organisasi untuk mengukur besar kecilnya kontribusi yang diberikan" (Marsaoly, 2016).

Keberhasilan organisasi tergantung pada kinerja para pelaku dalam organisasi tersebut. Agar kinerja sumber daya manusia yang terdapat dalam unit-unit dalam suatu organisasi tersebut dapat dinilai secara objektif maka harus dilakukan penilaian kinerja pada tiap unit kerja. Kesalahan atau penyimpangan yang dilakukan bawahan yang selalu mendapat pengarahan dari atasannya biasanya lebih sedikit dibandingkan dengan bawahan yang jarang diarahkan oleh atasannya. Beberapa faktor yang mempengaruhi tinggi rendahnya kinerja diantaranya pengawasan dan fasilitas.

Proses pemantauan, pemeriksaan dan evaluasi yang dilakukan secara berkesinambungan oleh atasan terhadap pegawai merupakan bentuk pengawasan. Pengawasan dilakukan untuk mengetahui kekurangan sehingga hal tersebut dapat diperbaiki demi tercapainya tujuan yang telah dirumuskan dalam perencanaan. "Fungsi dalam manajemen fungsional yang harus dilaksanakan oleh setiap pimpinan semua unit atau satuan kerja terhadap pelaksanaan pekerjaan di lingkungannya adalah pengawasan" (Kadarisman, 2014). Kegiatan untuk menemukan, mengoreksi penyimpangan dalam hasil yang dicapai dari aktivitas yang direncanakan disebut sebagai Pengawasan atau controlling.

(Rompas et al., 2018) dalam penelitian terdahulu menyimpulkan bahwa ada pengaruh signifikan pengawasan terhadap kinerja pegawai pada Dinas Perhubungan Kabupaten Minahasa Tenggara. Hasil ini sejalan dengan penelitian Harpis \& Bahri, (2020) bahwa pengawasan berpengaruh positif dan signifikan yang menunjukkan bahwa pengaruhnya terhadap kinerja kuat sekali.

Selain pengawasan maka kinerja juga dapat dipengaruhi oleh fasilitas. Diperlukan fasilitas kerja yang lengkap serta memadai dalam bekerja sehingga kinerja pegawai akan maksimal. "Sarana yang diberikan perusahaan untuk mendukung jalannya perusahaan dalam mencapai tujuan yang ditetapkan oleh pimpinan disebut sebagai fasilitas" (Barry, 2012).

Untuk memperoleh kinerja pegawai yang maksimal sebuah organisasi sangat mengandalkan fasilitas kerja yang tersedia dengan lengkap. Hal ini akan mempermudah dalam menyelesaikan suatu pekerjaan dengan hasil kerja yang efektif dan efisien. Sebagaimana Chasanah \& Rustiana, (2017) yang melakukan penelitian terdahulu, bahwa di Kantor Kecamatan se Kabupaten Batang terdapat pengaruh fasilitas kerja terhadap kinerja. Sejalan dengan hal tersebut, 
hasil penelitian Harpis \& Bahri, (2020) bahwa fasilitas kerja terhadap kinerja mempunyai pengaruh positif dan signifikan.

Selain dipengaruhi oleh pengawasan dan fasilitas, motivasi diduga dapat memoderasi pengaruh keduanya terhadap kinerja. Aktifitas yang menyebabkan seseorang menyelesaikan pekerjaannya dengan penuh semangat, ikhlas dan bertanggung jawab disebut motivasi. Fungsi motivasi adalah sebagai penggerak dan pendorong pegawai agar mau bekerja demi tercapainya tujuan organisasi denngan baik secara gigih dan tekun. "Motivasi adalah memberi dorongan sehingga tercipta gairah kerja seseorang, agar mereka mau bekerja secara bersama, efektif dan berintegrasi dengan segala kemampuan dalam mencapai kepuasan" (Hasibuan, 2010).

Salah satu faktor penting dalam mendorong seseorang untuk menghasilkan kinerja adalah motivasi. Sikap dan nilai-nilai yang mempengaruhi seseorang untuk mencapai hal yang khusus sesuai dengan tujuan pribadi. Sikap dan nilai tersebut memberikan kekuatan untuk mendorong individu untuk bertingkah laku dalam mencapai tujuan yang merupakan suatu yang tidak terlihat. Pribadi yang termotivasi maka akan berusaha secara maksimal dalam mencapai tujuan. Akan tetapi usaha yang tinggi tidak selamanya akan menghasilkan kinerja yang tinggi. Maka diperlukan intensitas dan kualitas dari upaya tersebut serta difokuskan pada tujuan organisasi. Biasanya kinerja yang tinggi dihubungkan dengan motivasi yang tinggi. Sedangkan, motivasi yang rendah dihubungkan dengan kinerja yang rendah. Kinerja dan motivasi bekerja akan berpengaruh positif karena saling membutuhkan.

Motivasi merupakan salah satu variabel moderasi yang dapat memperkuat atau memperlemah pengaruh variabel independen terhadap variabel dependen. Penelitian terdahulu yang dilakukan oleh (Jufrizen, 2018) menyatakan bahwa motivasi kerja dapat memoderasi hubungan antara kompensasi kerja terhadap kinerja. Selanjutnya (Nurhayati et al., 2017) dalam penelitian terdahulu menyebutkan bahwa motivasi mampu memperkuat pengaruh kepemimpinan pada kinerja Bendahara Desa di Kabupaten Tabanan. Sejalan dengan penelitian yang dilakukan (Firmandari, 2014) menyatakan bahwa motivasi memoderasi pengaruh variabel gaji dan variabel tunjangan terhadap kinerja pegawai Bank Mandiri Syariah Kantor Cabang Yogyakarta. Penelitian (Dwi \& Triastity, 2011) menyimpulkan bahwa motivasi memoderasi pengaruh variabel kecerdasan emosional dan variabel komitmen organisasi terhadap kinerja perawat Rumah Sakit Panti Rahayu Purwodadi.

Penelitian yang menambahkan motivasi sebagai variabel moderasi belum banyak dilakukan. Terutama yang menggunakan pengawasan dan 
fasilitas sebagai variabel independen. Berdasarkan hasil penelusuran penelitian terdahulu, peneliti hanya menemukan penelitian Sonia, (2019) yang menyimpulkan jika motivasi bekerja tidak memoderasi pengaruh pegawasan internal terhadap kinerja pegawai. Sedangkan penelitian tentang motivasi memoderasi pengaruh fasilitas terhadap kinerja belum ditemukan. Hal tersebut merupakan alasan bagi peneliti untuk menambahkan motivasi sebagai variabel moderating pada penelitian ini.

Demikian pula halnya dengan Dinas Pertanian Kabupaten Labuhanbatu Utara, sangat memperhatikan kinerja para pegawainya. Sebagai instansi yang mengurus tentang pertanian, perkebunan, peternakan dan perikanan di wilayah Kabupaten Labuhanbatu Utara, memiliki penyuluh pertanian yang dituntut untuk menunjukkan kinerja yang baik. Untuk memastikan agar kinerja para penyuluh berjalan dengan baik maka pimpinan melalukan pengawasan terhadap setiap pekerjaan yang dilakukan para penyuluh pertanian. Disamping itu Dinas Pertanian juga memberian fasilitas kerja agar mendukung kinerja para penyuluh pertanian. Hal ini diperlukan agar mampu mendukung pencapaian visi misi dan tujuan dari Dinas Pertanian.

Penelitian ini dilakukan dengan tujuan (1) menguji dan menganalisis pengaruh pengawasan terhadap Kinerja Penyuluh Dinas Pertanian Kabupaten Labuhanbatu Utara, (2) menguji dan menganalisis pengaruh fasilitas terhadap Kinerja Penyuluh Dinas Pertanian Kabupaten Labuhanbatu Utara, (3) menguji dan menganalisis motivasi memoderasi pengaruh pengawasan terhadap Kinerja Penyuluh Dinas Pertanian Kabupaten Labuhanbatu Utara, dan (4) enguji dan menganalisis motivasi memoderasi pengaruh fasilitas terhadap Kinerja Penyuluh Dinas Pertanian Kabupaten Labuhanbatu Utara.

\section{METODE PENELITIAN}

Penelitian ini diklasifikasikan sebagai penelitian asosiatif kausal dengan pendekatan deskriptif kuantitatif. Metode asosiatif merupakan metode yang bertujuan untuk menjelaskan hubungan kausal dan pengaruh antara variabelvariabel melalui pengujian hipotesis. Menurut (Sugiyono, 2012) bahwa "asosiatif adalah penelitian yang bertujuan untuk mengetahui pengaruh ataupun hubungan antara dua variabel atau lebih". "Penelitian deskriptif dibuat dan disusun secara tersistematis, akurat dan faktual. Umumnya ditulis dengan cara mengambarkan dan mendeskripsikan. Terkait variabel yang diteliti, bisa menggunakan satu variabel maupun lebih dari satu variabel. Kuantitatif adalah metode penelitian yang bersifat numerik, memiliki karakteristiks khusus, yaitu menggunakan cara berfikir secara deduktif atau rasional dan empiris. 
Adapun tujuannya yaitu menyusun ilmu nomotetik, atau disebut juga dengan ilmu yang dapat membuat hukum-hukum atau generalisasi" (Novia, 2019).

Populasi penelitian ini adalah penyuluh PNS Dinas Pertanian Kabupaten Labuhanbatu Utara sebanyak 34 responden. Penelitian ini menggunakan Teknik Sampling Jenuh. Menurut (Sugiyono, 2016) "sampling jenuh adalah teknik penentuan sampel bila semua anggota populasi dijadikan sampel". Menurut (Arikunto, 2013) "jika jumlah populasinya kurang dari 100 responden, maka jumlah sampelnya diambil secara keseluruhan". Maka jumlah sampel yang digunakan dalam penelitian ini yaitu 34 penyuluh PNS Dinas Pertanian Kabupaten Labuhanbatu Utara.

Pengumpulan data menggunakan instrumen penelitian berupa kuesioner/ angket. Skala yang dipakai dalam penelitian adalah Skala Likert. Teknik analisis data yang digunakan untuk menganalisis data dengan cara mendeskripsikan atau menggambarkan data yang telah terkumpul menggunakan Struktural Equation Modeling Partial Least Squares (SEM-PLS) dengan program SmartPLS 3.0. Terdapat dua model yang digunakan untuk analisa SEM-PLS, yakni model pengukuran (outer model) untuk menguji validitas dan reliabilitas suatu konstruk dan model struktural (inner model) untuk menguji pengaruh variabel laten eksogen tertentu terhadap variabel laten endogen apakah mempunyai pengaruh yang substantif. Kemudian pengujian hipotesis dengan konstruk utama dan pengujian hipotesis dengan efek moderasi.

\section{HASIL DAN PEMBAHASAN}

Hasil

\section{Uji Model Pengukuran}

Analisis model pengukuran berfungsi untuk memastikan apakah indikator- indikator yang digunakan dalam mengukur variabel laten reliabel dan valid. Setelah model pengukuran selesai dibuat seperti yang terlihat pada Gambar maka model siap diestimasi dengan menggunakan algoritma PLS yang sudah tersedia pada perangkat lunak SmartPLS 3.0.

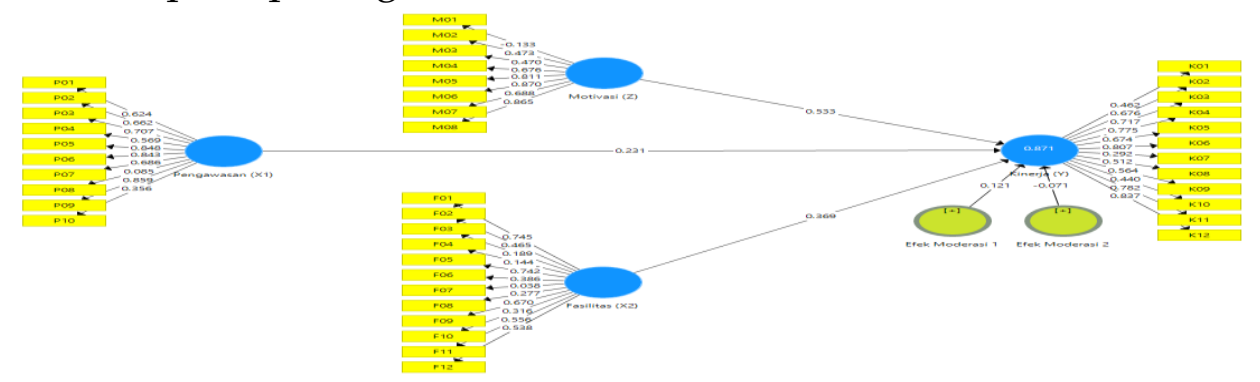

Gambar 1. Path Coefficients Algoritma PLS

Discriminant Validity 
Menilai validitas dari konstruk dapat dilakukan dengan melihat nilai Average Variance Extracted (AVE) . (Ghozali \& Latan, 2015) menjelaskan "untuk menilai validitas dari konstruk dengan melihat nilai AVE. Model dikatakan baik apabila AVE masing-masing konstruk nilainya lebih besar dari 0,50".

Tabel 1. Uji Discriminant Validity Variabel Penelitian

\begin{tabular}{ccc}
\hline Variabel & AVE & Keterangan \\
\hline Kinerja & 0,52 & Valid \\
Pengawasan & 0,59 & Valid \\
Fasilitas & 0,50 & Valid \\
Motivasi & 0,63 & Valid
\end{tabular}

Sumber: Pengolahan Data (2021)

Hasil pada Tabel di atas menunjukkan seluruh variabel penelitian memiliki nilai AVE lebih dari 0,5. Sehingga dapat disimpulkan bahwa seluruh variabel laten atau konstruk dalam penelitian memenuhi syarat Discriminant Validity.

Uji Reliabilitas

Uji reliabilitas dilakukan untuk membuktikan akurasi, konsistensi dan ketepatan instrumen dalam mengukur konstruk. Mengukur reliabilitas suatu konstruk dengan indikator reflektif dalam PLS-SEM menggunakan program SmartPLS 3.0 dilakukan dengan dua cara, yaitu dengan Cronbach's Alpha dan Composite Reliability. "Konstruk dinyatakan reliabel jika nilai Cronbach's Alpha maupun Composite Reliability lebih dari 0,70" (Ghozali \& Latan, 2015).

Tabel 2. Uji Reliabilitas Variabel Penelitian

\begin{tabular}{ccccc}
\hline Variabel & $\begin{array}{c}\text { Cronbach's } \\
\text { Alpha }\end{array}$ & Keterangan & $\begin{array}{c}\text { Composite } \\
\text { Reliability }\end{array}$ & Keterangan \\
\hline Kinerja & 0,88 & Reliabel & 0,90 & Reliabel \\
Pengawasan & 0,90 & Reliabel & 0,92 & Reliabel \\
Fasilitas & 0,79 & Reliabel & 0,83 & Reliabel \\
Motivasi & 0,85 & Reliabel & 0,89 & Reliabel \\
\hline
\end{tabular}

Sumber: Pengolahan Data (2021)

Berdasarkan hasil pada tabel di atas, seluruh variabel laten atau konstuk memiliki nilai Cronbach's Alpha maupun Composite Reliability lebih dari 0,7. Sehingga seluruh variabel laten yang digunakan pada penelitian ini dinyatakan memenuhi syarat reliabilitas konsistensi internal.

\section{Uji Model Struktural}

Pengujian model struktural akan menghasilkan estimasi koefisien jalur dan tingkat signifikansi yang digunakan untuk pengujian hipotesis. Pada SEMPLS uji model struktural dilakukan setelah uji validitas dan uji reliabilitas model pengukuran terpenuhi. "Pengujian terhadap model struktural dilakukan 
dengan melihat nilai $R$-Square. Nilai $R$-Square 0,75 menunjukkan bahwa model kuat. Nilai $R$-Square 0,50 menunjukkan bahwa model moderat. Nilai $R$-Square 0,25 menunjukkan bahwa model lemah" (Ghozali \& Latan, 2015).

Tabel 3. Uji Struktural Variabel Penelitian

\begin{tabular}{ccc}
\hline Variabel & $R$-Square & Keterangan \\
\hline Kinerja & 0,83 & Kuat \\
Pengawasan & - & - \\
Fasilitas & - & - \\
Motivasi & - & - \\
\hline
\end{tabular}

Sumber: Pengolahan Data (2021)

Nilai $R$-Square sebesar 0,83 pada variabel kinerja menunjukkan bahwa model pada kategori kuat. Nilai tersebut memperlihatkan bahwa tiga variabel pengawasan, fasilitas dan motivasi secara kuat menjelaskan $83 \%$ variansi dari variabel kinerja.

\section{Uji Hipotesis}

Uji Hipotesis Konstruk Utama

Menjalankan algoritma Bootstrapping pada aplikasi SmartPLS 3.0 akan menghasilkan nilai T-Statistics. Nilai minimal T-Statistics untuk menilai signifikan atau tidaknya hubungan dari variabel laten satu dengan variabel laten lain tergantung dari nilai signifikansi yang digunakan. "Pada tingkat signifikansi 5\%, nilai T-Statistics minimal sebesar 1,96" (Hair et al., 2011).

Tabel 4. Uji Hipotesis Konstruk Utama

\begin{tabular}{lcccc}
\hline \multicolumn{1}{c}{ Hubungan } & $\begin{array}{c}\text { Original } \\
\text { Sample }\end{array}$ & T-Statistics & Hipotesis & Keterangan \\
\hline Pengawasan => Kinerja & 0,18 & 2,14 & Berpengaruh & Diterima \\
Fasilitas => Kinerja & 0,36 & 2,87 & Berpengaruh & Diterima \\
Motivasi => Kinerja & 0,56 & 4,60 & - & Berpengaruh \\
\hline
\end{tabular}

Sumber: Pengolahan Data (2021)

Tabel di atas menunjukkan, diketahui hipotesis pertama penelitian ini bahwa pengawasan berpengaruh terhadap kinerja penyuluh Dinas Pertanian Kabupaten Labuhanbatu Utara diterima. Nilai T-Statistics variabel pengawasan terhadap kinerja sebesar 2,14 lebih besar dari nilai kritisnya 1,96. Hal ini menunjukkan bahwa pengawasan berpengaruh positif dan signifikan terhadap kinerja penyuluh.

Selanjutnya hipotesis kedua tentang fasilitas berpengaruh terhadap kinerja penyuluh Dinas Pertanian Kabupaten Labuhanbatu Utara juga diterima. Nilai Nilai T-Statistics variabel fasilitas terhadap kinerja sebesar 2,87 juga lebih besar dari nilai kritisnya 1,96. hal ini juga membuktikan bahwa fasilitas berpengaruh positif dan signifikan terhadap kinerja penyuluh. 
Hasil dari algoritma Bootstrapping juga menunjukkan bahwa secara langsung variabel motivasi berpengaruh positif dan signifikan terhadap kinerja penyuluh. Nilai T-Statistics yang diperoleh sebesar 4,60 merupakan yang terbesar dibanding variabel lainnya.

Uji Hipotesis dengan Efek Modrasi

Analisis efek moderasi dilakukan untuk mengetahui nilai signifikansi dari motivasi sebagai variabel moderasi dengan variabel eksogen terhadap variabel endogen. Signifikansi dapat ditentukan melalui nilai P-Values yang dihasilkan menggunakan Algoritma Bootstrapping pada aplikasi SmartPLS 3.0, yakni $P$-Values $<0,05$.

Tabel 5. Uji Hipotesis Dengan Efek Moderasi

\begin{tabular}{ccccc}
\hline Hubungan & $\begin{array}{c}\text { Original } \\
\text { Sample }\end{array}$ & P-Values & Hipotesis & Keterangan \\
\hline Efek Moderasi 1 => Kinerja & $-0,05$ & 0,70 & Memoderasi & Ditolak \\
Efek Moderasi 2 => Kinerja & 0,00 & 0,97 & Memoderasi & Ditolak \\
\hline
\end{tabular}

Sumber: Pengolahan Data (2021)

Tabel di atas menunjukkan hipotesis ketiga penelitian ini yakni motivasi memoderasi pengaruh pengawasan terhadap kinerja penyuluh Dinas Pertanian Kabupaten Labuhanbatu Utara ditolak. Nilai P-Values efek moderasi 1 terhadap kinerja sebesar 0,70 lebih besar dari 0,05.

Hipotesis keempat tentang motivasi memoderasi pengaruh fasilitas terhadap kinerja penyuluh Dinas Pertanian Kabupaten Labuhanbatu Utara juga ditolak. Nilai $P$-Values efek moderasi 2 terhadap kinerja sebesar 0,97 lebih besar dari 0,05 .

\section{Pembahasan}

Penilaian kinerja penyuluh dilakukan dengan tujuan untuk membantu tercapainya dan meningkatnya standar kinerja para penyuluh, membantu penyuluh dalam mengidentifikasi pengetahuan dan keterampilan yang dibutuhkan dalam menjalankan pekerjaan dengan efektif. Membantu penyuluh agar bekerja sesuai dengan arah dan tujuan yang telah ditetapkan oleh organisasi serta memperoleh umpan balik peningkatan pengembangan diri.

Hasil pengujian menunjukkan bahwa tiga variabel pengawasan, fasilitas dan motivasi secara kuat menjelaskan $83 \%$ variansi dari variabel kinerja. Sedangkan sisanya 17\% dipengaruhi oleh faktor-faktor lain. Diperoleh hasil bahwa pengawasan dan fasilitas berpengaruh terhadap kinerja penyuluh. Motivasi tidak memoderasi pengaruh pengawasan dan fasilitas terhadap kinerja penyuluh. 
Page 77-93

\section{Pengawasan Berpengaruh terhadap Kinerja Penyuluh}

Dari hasil penelitian terlihat nilai analisis data Original Sample adalah positif sebesar 0,18 yang menunjukkan bahwa hubungan pengawasan dengan kinerja adalah positif. Nilai T-Statistics sebesar 2,14 lebih besar dari nilai kritisnya 1,96. Hal ini menunjukkan bahwa ada pengaruh positif dan signifikan pengawasan terhadap kinerja penyuluh.

Hasil penelitian ini didukung oleh penelitian (Jufrizen, 2016), (Situmeang, 2017), (Nielwaty et al., 2017), (Putra, 2018), (Joko \& Munir, 2019), (Sjahrir, 2019), (Harpis \& Bahri, 2020), (A. Rivai, 2021) dan (Parlindungan et al., 2021) yang menyebutkan bahwa pengawasan berpengaruh positif dan signifikan terhadap kinerja pegawai. Namun penelitian (Nasution \& Pasaribu, 2020), (Qodri, 2018), (Lukas et al., 2017) dan (Dewi, Harlen, \& Sasmita, 2015) tidak mendukung bahwa tidak ada pengaruh signifikan pengawasan terhadap kinerja pegawai.

Dengan demikian jika Dinas Pertanian Kabupaten Labuhanbatu Utara mampu melakukan pengawasan dengan baik, maka akan mempengaruhi peningkatan kinerja penyuluh pertanian. Sebaliknya jika Dinas Pertanian Kabupaten Labuhanbatu Utara tidak melakukan pengawasan dengan baik, maka akan memungkinkan terjadinya penurunan kinerja penyuluh.

Bahwa masalah yang timbul karena pengawasan yang kurang terhadap penyuluh. Wilayah kerja penyuluh yang tersebar di seluruh desa/ kelurahan se-Kabupaten Labuhanbatu Utara dengan jarak tempuh yang lumayan jauh menjadikan pengawasan belum berjalan maksimal, Target kunjungan ke kelompok tani sebanyak 32 (tiga puluh dua) kali dalam sebulan juga tidak terlaksana dengan baik. Jika sejak awal pihak Dinas Pertanian memperhatikan penempatan wilayah kerja penyuluh berdasarkan lokasi tempat tinggalnya serta melakukan pengawasan terpusat, maka kemungkinan masalah penurunan kinerja penyuluh tidak akan terjadi. Oleh sebab itu, sebaiknya pihak Dinas Pertanian Kabupaten Labuhanbatu Utara harus memperhatikan pengawasan terpusat terhadap para penyuluh dan melakukan penempatan ulang wilayah kerja penyuluh pertanian berbasis jarak tempuh dari tempat tinggal. Diharapkan hal tersebut akan mampu meningkatkan kinerja para penyuluh pertanian.

\section{Fasilitas Berpengaruh terhadap Kinerja Penyuluh}

Berdasarkan hasil penelitian terlihat nilai analisis data Original Sample adalah positif sebesar 0,36 yang menunjukkan bahwa hubungan fasilitas dengan kinerja adalah positif. Nilai T-Statistics sebesar 2,87 lebih besar dari nilai kritisnya 1,96. Hal ini menunjukkan bahwa ada pengaruh positif dan signifikan fasilitas terhadap kinerja penyuluh. 
Hasil penelitian ini didukung oleh penelitian (Jufrizen \& Hadi, 2021), (Manurung et al., 2021), (Harpis \& Bahri, 2020), (Asri et al., 2019), (Anam \& Rahardja, 2017), (Listyani, 2016) dan (Wahyuni, 2014) yang menyebutkan bahwa fasilitas berpengaruh positif dan signifikan terhadap kinerja pegawai. Namun penelitian (Irawan \& Suryani, 2018) dan (Kelatow et al., 2016) tidak mendukung bahwa tidak ada pengaruh signifikan fasilitas terhadap kinerja pegawai.

Dengan demikian jika Dinas Pertanian Kabupaten Labuhanbatu Utara mampu melengkapi fasilitas kerja dengan baik, maka akan mempengaruhi peningkatan kinerja penyuluh pertanian. Sebaliknya jika Dinas Pertanian Kabupaten Labuhanbatu Utara tidak melengkapi fasilitas kerja tersebut, maka akan memungkinkan terjadinya penurunan kinerja penyuluh.

Bahwa masalah yang timbul karena kurang lengkapnya fasilitas yang berdampak pada menurunnya kinerja penyuluh. Fasilitas yang dimaksud adalah ruangan yang kurang nyaman karena belum tersedianya kipas angin maupun AC, alat teknologi berupa komputer, mesin fotokopi, scanner, telepon, internet, serta kondisi kendaraan dinas yang perlu diremajakan. Sehingga jika sejak awal pihak Dinas Pertanian memperhatikan hal tersebut, maka kemungkinan masalah penurunan kinerja penyuluh tidak akan terjadi. Dengan demikian, sebaiknya pihak Dinas Pertanian Kabupaten Labuhanbatu Utara harus memperhatikan fasilitas yang dibutuhkan oleh penyuluh berupa ruangan yang nyaman, mesin elektronik maupun kendaraan dinas yang sehat. Hal tersebut diharapkan mampu meningkatkan kinerja para penyuluh pertanian.

Motivasi tidak Memoderasi Pengaruh Pengawasan terhadap Kinerja Penyuluh

Dari hasil penelitian terlihat nilai analisis data Original Sample adalah negatif sebesar 0,05 yang menunjukkan bahwa hubungan efek moderasi 1 dengan kinerja adalah negatif. Nilai $P$-Values sebesar 0,70 lebih besar dari 0,05. Hal ini menunjukkan bahwa motivasi tidak dapat memoderasi pengaruh pengawasan terhadap kinerja penyuluh pertanian.

Hasil penelitian ini didukung oleh penelitian (Sonia, 2019) yang menyebutkan bahwa motivasi bekerja tidak memoderasi pengaruh pegawasan internal terhadapkinerja pegawai di Kabupaten Serdang Bedagai.

Secara langsung pengaruh motivasi terhadap kinerja penyuluh dapat dilihat dari nilai analisis data Original Sample adalah positif sebesar 0,56 yang menunjukkan bahwa hubungan motivasi dengan kinerja adalah positif. Nilai $T$ Statistics sebesar 4,60 lebih besar dari nilai kritisnya 1,96. Hal ini menunjukkan bahwa ada pengaruh positif dan signifikan motivasi terhadap kinerja 
penyuluh. Maka dapat disimpulkan bahwa motivasi bukan merupakan variabel yang memoderasi pengaruh pengawasan terhadap kinerja.

Dengan demikian jika Dinas Pertanian Kabupaten Labuhanbatu Utara mampu meningkatkan motivasi penyuluh untuk lebih baik dalam bekerja, maka akan mempengaruhi peningkatan kinerja penyuluh pertanian. Sebaliknya jika Dinas Pertanian Kabupaten Labuhanbatu Utara tidak meningkatkan motivasi tersebut, maka akan memungkinkan terjadinya penurunan kinerja penyuluh.

Bahwa masalah yang timbul karena sebagian penyuluh memiliki motivasi yang kurang. Hal ini mungkin disebabkan penghargaan yang kurang diberikan kepada penyuluh. Besaran Tambahan Penghasilan Pegawai (TPP) yang diperoleh penyuluh lebih kecil dari pegawai struktural, sehingga menyebabkan menurunnya rasa tanggung jawab. Dengan demikian, sebaiknya pihak Dinas Pertanian Kabupaten Labuhanbatu Utara harus lebih memotivasi penyuluh dalam hal penempatan rekan kerja dalam satu Balai Penyuluhan Pertanian, fokus pada tujuan organisasi dan rasa tanggung jawab yang disesuaikan dengan peningkatan penghargaan berupa kesempatan belajar dan tambahan penghasilan tentunya. Hal tersebut diharapkan mampu meningkatkan kinerja para penyuluh pertanian.

\section{Motivasi tidak Memoderasi Pengaruh Fasilitas terhadap Kinerja Penyuluh}

Dari hasil penelitian terlihat nilai analisis data Original Sample adalah positif sebesar 0,00 yang menunjukkan bahwa hubungan efek moderasi 2 dengan kinerja adalah potitif. Nilai $P$-Values sebesar 0,97 lebih besar dari 0,05. Hal ini juga menunjukkan bahwa motivasi tidak dapat memoderasi pengaruh fasilitas terhadap kinerja penyuluh pertanian.

Hasil ini semakin memperkuat bahwa pada penelitian ini, motivasi bukan merupakan variabel yang moderasi pengaruh pengawasan terhadap kinerja maupun pengaruh fasilitas terhadap kinerja. Motivasi secara langsung berpengaruh terhadap kinerja penyuluh pertanian.

Motivasi merupakan variabel moderasi pada pengaruh beberapa variabel independen terhadap variabel dependen. Diantaranya pada pengaruh hubungan antara kompensasi kerja terhadap kinerja (Jufrizen, 2018). Motivasi mampu memperkuat pengaruh kepemimpinan pada kinerja bendahara (Nurhayati et al., 2017). Motivasi memperkuat hubungan antara karakteristik individu, budaya organisasi, dan komitmen organisasi terhadap kinerja karyawan (Susanti, 2016). Kemudian motivasi mampu memoderasi pengaruh variabel gaji dan variabel tunjangan terhadap kinerja karyawan (Firmandari, 2014). Motivasi juga memoderasi pengaruh variabel kecerdasan emosional dan variabel komitmen organisasi terhadap kinerja perawat (Dwi \& Triastity, 2011). 
Motivasi berpengaruh terhadap hubungan antara disiplin kerja dengan kinerja pegawai (Surajiyo et al., 2021). Pengaruh pelatihan terhadap prestasi kerja bergantung pada motivasi kerja (H. A. Rivai et al., 2018). Motivasi dapat memoderasi hubungan antara lingkungan kerja dan transfer pelatihan" (Noorizam et al., 2016). Motivasi merupakan moderasi yang memiliki pengaruh yang kuat pada hubungan antara kompensasi dan kinerja karyawan (Rizal et al., 2014). Motivasi memoderasi hubungan pendekatan pembelajaran dengan prestasi belajar (Bakhtiarvand et al., 2011).

Namun sebaliknya motivasi tidak memoderasi pengaruh beberapa variabel independen terhadap variabel dependen. Motivasi tidak bertindak sebagai moderasi terhadap pengaruh budaya organisasi terhadap kinerja karyawan (Jufrizen et al., 2021). Motivasi tidak memoderasi pada hubungan antara disiplin kerja terhadap kinerja (Jufrizen, 2018). Motivasi tidak mampu memoderasi pengaruh kompetensi pada kinerja bendahara dan motivasi tidak mampu memoderasi pengaruh lingkungan kerja pada kinerja bendahara (Nurhayati et al., 2017). Kemudian motivasi kerja tidak memoderasi pengaruh persepsi terhadap kinerja pegawai dan motivasi kerja tidak memoderasi pengaruh budaya organisasi terhadap kinerja pegawai (Rahmawaty, 2017). Motivasi tidak memoderasi pengaruh variabel bonus terhadap kinerja karyawan (Firmandari, 2014). Motivasi juga tidak memoderasi pengaruh pengawasan terhadap kinerja dan pengaruh fasilitas terhadap kinerja pada penelitian ini.

Kinerja penyuluh dinilai belum maksimal. Hal tersebut ditandai oleh menurunnya hasil kerja yang dicapai dari sebagian penyuluh khususnya dalam melaksanakan pekerjaan yang telah ditentukan oleh atasan. Sasaran Kinerja Pegawai (SKP) penyuluh pertanian mengalami penurunan dari tahun sebelumnya. Perlu dilakukan upaya untuk meningkatkan kinerja tersebut. Dinas Pertanian Kabupaten Labuhanbatu Utara harus mampu meningkatkan kinerja para penyuluh, yakni dengan melakukan pengawasan dan memberikan fasilitas yang maksimal bagi penyuluh agar lebih termotivasi dalam bekerja.

\section{KESIMPULAN}

Berdasarkan hasil analisis data yang telah dilakukan serta pembahasan yang telah dikemukakan sebelumnya, maka dapat ditarik kesimpulan bahwa pengawasan berpengaruh positif dan signifikan terhadap kinerja penyuluh Dinas Pertanian Kabupaten Labuhanbatu Utara. Fasilitas berpengaruh positif dan signifikan terhadap kinerja penyuluh Dinas Pertanian Kabupaten Labuhanbatu Utara. Motivasi tidak memoderasi pengaruh pengawasan terhadap kinerja penyuluh Dinas Pertanian Kabupaten Labuhanbatu Utara. 
Motivasi tidak memoderasi pengaruh fasilitas terhadap kinerja penyuluh Dinas Pertanian Kabupaten Labuhanbatu Utara. Secara langsung motivasi berpengaruh positif dan signifikan terhadap kinerja penyuluh Dinas Pertanian Kabupaten Labuhanbatu Utara.

Berdasarkan kesimpulan di atas maka saran yang dapat diberikan pada penelitian ini kepada Dinas Pertanian Kabupaten Labuhanbatu Utara adalah meningkatkan pemahaman kepada para penyuluh terhadap rasa tanggung jawab (responsibility awareness) terhadap pekerjaan bahwa pekerjaan yang dilakukan merupakan selain merupakan tanggung jawab juga merupakan sarana beribadah kepada Allah. Fasilitas yang diberikan organisasi kepada penyuluh agar lebih ditingkatkan lagi sehingga penyuluh merasa puas dalam melakukan pekerjaan yang selanjutnya akan berdampak pula pada meningkatnya kinerja. Memaksimalkan penggunaan aplikasi absensi E-Gov Labura berbasis pengenalan wajah dan lokasi keberadaan penyuluh dengan baik dan sesuai prosedur yang berlaku sehingga akan berdampak terhadap kinerja penyuluh yang lebih baik. Mengalokasikan biaya perawatan terhadap fasilitas yang digunakan oleh penyuluh sebagai dorongan dan penyemangat dalam bekerja sehingga berdampak terhadap peningkatan kinerja. Motivasi kerja penyuluh perlu dipertahankan dengan memenuhi kebutuhannya agar nyaman dan bertanggung jawab dalam melakukan pekerjaan.

\section{REFERENCES}

Anam, K., \& Rahardja, E. (2017). Pengaruh Fasilitas Kerja, Lingkungan Kerja non Fisik dan Kepuasan Kerja Terhadap Kinerja Karyawan (Studi pada Pegawai Dinas Perindustrian dan Perdagangan Provinsi Jawa Tengah). 6(4), 1-11.

Arikunto, S. (2013). Prosedur Penelitian Suatu Pendekatan Praktik. Rineka Cipta.

Asri, Ansar, \& Munir, A. R. (2019). Pengaruh Kompensasi, Fasilitas Kerja dan Kepemimpinan terhadap Kinerja Melalui Kepuasan Kerja Pegawai pada Rektorat UIN Alauddin Makassar. YUME : Journal of Management, 2(1), 121.

Bakhtiarvand, F., Ahmadian, S., Delrooz, K., \& Farahani, H. A. (2011). The Moderating Effect of Achievement Motivation on Relationship of Learning Approaches and Academic Achievement. Procedia - Social and Behavioral Sciences, 28, 486-488.

Barry, C. (2012). Human Resource Management. PT. Elex Media Kumputindo.

Chasanah, I., \& Rustiana, A. (2017). Pengaruh Kemampuan Kerja, Fasilitas Kerja, dan Prinsip Prosedur Kerja terhadap Kinerja Pegawai di Kantor Kecamatan se Kabupaten Batang. 6(2), 433-446.

Dewi, I. S. K., Harlen, \& Sasmita, J. (2015). Pengaruh Budaya Organisasi dan 
Pengawasan terhadap Kinerja melalui Komitmen Karyawan Frontliner PT Bank Riau Kepri. Jurnal Tepak Manajemen Bisnis, VII(2), 179-191.

Dwi, A., \& Triastity, R. (2011). Pengaruh Kecerdasan Emosional dan Komitmen Organisasi terhadap Kinerja dengan Motivasi Kerja sebagai Variabel Moderasi. Jurnal Manajemen Sumberdaya Manusia, 5(2), 145-158.

Firmandari, N. (2014). Pengaruh Kompensasi terhadap Kinerja Karyawan dengan Motivasi Kerja sebagai Variabel Moderasi (Studi pada Bank Syariah Mandiri Kantor Cabang Yogyakarta). Ekbisi, IX(1), 25-34.

Ghozali, I., \& Latan, H. (2015). Partial Least Square Konsep Teknik dan Aplikasi Menggunakan Program SmartPLS 3.0. Badan Penerbit Universitas Diponegoro.

Hair, J. F., Ringle, C. M., \& Sarstedt, M. (2011). PLS-SEM: Indeed a Silver Bullet. Journal of Marketing Theory and Practice, 19(2), 139-152.

Harpis, M., \& Bahri, S. (2020). Pengaruh Fasilitas Kerja, Pengawasan dan Kompensasi Terhadap Kinerja Pegawai pada Dinas Pekerjaan Umum dan Penataan Ruang Kabupaten Serdang Bedagai. Maneggio: Jurnal Ilmiah Magister Manajemen, 3(1), 13-28.

Hasibuan, M. (2010). Organisasi dan Motivasi Dasar Peningkatan Produktivitas. PT. Bumi Aksara.

Irawan, A., \& Suryani, N. (2018). Pengaruh Gaya Kepemimpinan, Fasilitas Kantor, dan Disiplin Kerja terhadap Kinerja Pegawai Dinas Perdagangan Kota Semarang. Economic Education Analysis Journal, 7(1), 265-278.

Joko, T., \& Munir, R. (2019). Pengaruh Pengembangan Karir, Pengawasan dan Komitmen Pegawai terhadap Kinerja Pegawai di Dinas Pengendalian Penduduk dan Keluarga Berencana Kabupaten Bantaeng. YUME : Journal of Management, 2(2), 1-16.

Jufrizen, J. (2016). Pengaruh Pengawasan terhadap Kinerja Karyawan Melalui Disiplin Kerja pada PT Socfin Indonesia - Medan. Jurnal Ilmiah Manajemen dan Bisnis, 17(02), 181-195.

Jufrizen, J. (2018). Peran Motivasi Kerja dalam Memoderasi Pengaruh Kompensasi dan Disiplin Kerja terhadap Kinerja Karyawan. The National Conferences Management and Business (NCMAB), 405-424.

Jufrizen, J., \& Hadi, F. P. (2021). Pengaruh Fasilitas Kerja dan Disiplin Kerja terhadap Kinerja Karyawan Melalui Motivasi Kerja. Jurnal Sains Manajemen, 7(1), 35-54.

Jufrizen, J., Mukmin, M., Nurmala, D., \& Jasin, H. (2021). Effect of Moderation of Work Motivation on the Influence of Organizational Culture on Organizational Commitment and Employee Performance. International Journal of Business Economics (IJBE), 2(2), 86-98. 
Journal Economy And Currency Study (JECS)

Volume 3, Issue 2, July 2021

Page 77-93

Kadarisman, M. (2014). Manajemen Pengembangan Sumber Daya Manusia. Rajawali Pers.

Kelatow, C. G., Adolfina, \& Trang, I. (2016). Pengaruh Evaluasi Pekerjaan, Gaji dan Fasilitas Kerja terhadap Kinerja Pegawai pada RS. Pancaran Kasih Manado. Jurnal EMBA: Jurnal Riset Ekonomi, Manajemen, Bisnis dan Akuntansi, 4(3), 371-381.

Listyani, I. (2016). Pengaruh Fasilitas Kerja dan Komunikasi Kerja terhadap Kinerja Karyawan. Jurnal Manajemen dan Kewirausahaan (Journal of Management and Entrepreneurship), 1(1), 56-64.

Lukas, M., Tewal, B., \& Walangitan, M. D. (2017). Pengaruh Pengawasan, Kepemimpinan dan Kompensasi terhadap Kinerja Pegawai pada Badan Pengelola Keuangan dan Barang Milik Daerah Kabupaten Minahasa Utara. Jurnal EMBA: Jurnal Riset Ekonomi, Manajemen, Bisnis dan Akuntansi, 5(2), 1921-1928.

Mangkunegara, A. P. (2018). Manajemen Sumber Daya Manusia Perusahaan (S. Sandiasih (ed.)). PT. Remaja Rosdakarya Offset.

Manurung, E., Nura, E. T., Nurdin, Metia, T. A., \& Isminingsih. (2021). Pengaruh Fasilitas Kerja, Kedisiplinan dan Pengawasan terhadap Kinerja Pegawai Dinas Perikanan Kota Tanjungbalai. Manajemen Bisnis Jurnal Magister Manajemen, 3(1), 38-47.

Marsaoly. (2016). Pengaruh Pengawasan dan Disiplin Kerja terhadap Kinerja Pegawai. Kencana Prenadamedia Group.

Nasution, S. N., \& Pasaribu, S. E. (2020). Pengaruh Pengawasan, Motivasi dan Disiplin Terhadap Kinerja Guru pada Yayasan Pendidikan Islam Terpadu Kuntum Bumi Rantauprapat. Maneggio: Jurnal Ilmiah Magister Manajemen, 3(1), 75-91.

Nielwaty, E., Prihati, \& Zuhdi, S. (2017). Pengaruh Pengawasan terhadap Kinerja Pegawai Disperindag Sub Bidang Penngawasan Barang dan Jasa Provinsi Riau. Jurnal Niara, 10(1), 1-5.

Noorizam, Fareeha, A. N., Norfazlina, \& Akma, S. (2016). The Moderating Effects of Motivation on Work Environment and Training Transfer: A Preliminary Analysis. Procedia Economics and Finance, 37(16), 158-163.

Novia, I. (2019). 3 Pendekatan dan Metode Penelitian. Menulis Karya Ilmiah. Deepublish. https://penerbitdeepublish.com/metode-penelitian/

Nurhayati, Astika, I. B. P., \& Wirakusuma, M. G. (2017). Kemampuan Motivasi Memoderasi Pengaruh Kompetensi, Kepemimpinan dan Lingkungan Kerja pada Kinerja Bendahara Desa di Kabupaten Tabanan. E-Jurnal Ekonomi dan Bisnis Universitas Udayana, 6(12), 4255-4282.

Parlindungan, R., Farisi, S., \& Nurhayati. (2021). Peningkatan Kinerja Pegawai: 
Peran Kepemimpinan Transformal, Pengawasan dan Kepuasan Kerja. Proceding Seminar Nasional Kewirausahaan, 2(1), 677-689.

Putra, W. E. (2018). Analisis Pengaruh Pengawasan Fungsional , Akuntabilitas Publik dan Peningkatan Pelayanan Publik terhadap Kinerja Pemerintah Daerah (Studi Empiris pada SKPD di Provinsi Jambi). Jurnal Akuntansi dan Pajak, 18(02), 181-187.

Qodri, I. H. (2018). Pengaruh Pengawasan dan Disiplin Kerja Terhadap Kinerja Pegawai Dinas Perhubungan Kota Samarinda. Jurnal Ilmu Manajemen Mulawarman, 3(4), 1-26.

Rahmawaty, D. (2017). Pengaruh Persepsi dan Budaya Organisasi terhadap Kinerja Pegawai dengan Motivasi Kerja sebagai Variabel Moderasi. Jurnal Benefita, 2(3), 278-287.

Rivai, A. (2021). Pengaruh Pengawasan, Disiplin dan Motivasi terhadap Kinerja Guru. 4(1), 11-22.

Rivai, H. A., Lukito, H., \& Fauzi, A. R. (2018). The Role of Work Motivation as Moderator in the Relationship between Training and Job Performance: A Study in Regional Hospital in West Sumatra Province. Unimed International Conference on Economics Education and Social Science, 1341-1348. https:/ / doi.org/10.5220/0009501013411348

Rizal, M., Idrus, M. S., Djumahir, \& Mintarti, R. (2014). Effect of Compensation on Motivation, Organizational Commitment and Employee Performance ( Studies at Local Revenue Management in Kendari City ). International Journal of Business and Management Invention, 3(2), 64-79.

Rompas, G. A. C., Tewal, B., \& Dotulong, L. (2018). Pengaruh Gaya Kepemimpinan, Pengawasan, dan Disiplin Kerja terhadap Kinerja Pegawai pada Dinas Perhubungan Kabupaten Minahasa Tenggara. Jurnal EMBA, 6(4), 1978-1987.

Situmeang, R. R. (2017). Pengaruh Pengawasan dan Pengalaman Kerja terhadap Kinerja Karyawan pada PT. Mitra Karya Anugrah. Asian Journal of Innovation and Entrepreneurship, 2(2), 148-160.

Sjahrir. (2019). Pengaruh Kapasitas Lelembagaan, Koordinasi, dan Pengawasan terhadap Akuntabilitas Kinerja Pemerintah Kota Bogor Provinsi Jawa Barat. Jurnal Kebijakan Pemerintahan, 2(1), 1-22.

Sonia, J. (2019). Pengaruh Implementasi Sistem Informasi Akuntansi, Pengawasan Internal dan Reward terhadap Kinerja Pegawai dengan Motivasi Bekerja sebagai Variabel Moderating di Kabupaten Serdang Bedagai. Universitas Sumatera Utara.

Sugiyono. (2012). Metode Penelitian Bisnis. Alfabeta.

Sugiyono. (2016). Metode Penelitian Kuantitatif, Kualitatif dan RED. Alfabeta. 
Surajiyo, Suwarno, Kesuma, I. M., \& Gustiherawati, T. (2021). The Effect of Work Discipline on Employees Performance with Motivation as a Moderating Variables in the Inspectorate Office of Musi Rawas District. nternational Journal of Community Service and Engagement, 2(1), 1-12.

Susanti, S. (2016). Pengaruh Karakteristik Individu, Budaya Organisasi terhadap Kinerja Karyawan dengan Motivasi sebagai Variabel Moderasi (Studi pada Karyawan Instalasi Rawat Jalan RSUD Dr. Saiful Anwar Malang). Ekonomika-Bisnis, 07(02), 153-160.

Wahyuni, S. (2014). Pengaruh Motivasi, Pelatihan dan Fasilitas Kerja Terhadap Kinerja Pegawai Dinas Pendapatan Daerah Provinsi Sulawesi Selatan. eJurnal katalogis Magister Manajemen Pascasarjana Universitas Tadulako, 2(1), 124-134. 